\title{
CHALLENGING HEGEMONIC CULTURAL TRADITION OF GHURCHARI IN HARYANA
}

\author{
Bhup Singh Gaur \\ Associate Prof. \\ Sociology, \\ DGC Gurugram, \\ Haryana
}

Article DOI: https://doi.org/10.36713/epra4219

\begin{abstract}
Kathopinishad describe the meaning of chariot and in marriage bridegroom riding female horse. The use of female horse not only suggests patriarchal intention to domesticate the wife but also control the women. On the commencement of the Indian constitution, they have become equal citizens in all aspects of life. They become aware of self respects, dignity and their rights enshrined in the Indian constitution. The upper castes or greater Indians still trest them as lesser Indians and expect them to stay at the bottom of the society. Recent caste conflicts on marriage ritual of ghurchari i.e dalit groom and family members seriously injured during ghurchari (jatu luhari, 2002), upper caste people prevented a dalit groom from riding an elephant (2011), killed in 2013, Devsar, upper caste men beat dalit groom and stopped him to perform ghurchari(2013, Ratera), upper caste youth barred dalit groom from carrying the ritual of ghurchari (sanjharwas, charki Dadri) violence broke out in the village sangha, karnal after upper caste youth prevented dalit youth from performing, ghurchari (2017) etc... clearly reflects the social position of the lesser Indians in India.

This was an exploratory study based on secondary sources such as newspapers and magazines. focussing on the hegemonic power, protest ideology, role of police and social relationship

KEYWORDS:- scheduled caste, Ghurchuri, hegemony, protest ideology
\end{abstract}

\section{INTRODUCTION}

In modern world marriage is about contract. The boy and girl choose each other and enter into the contract. The traditional Hindu wedding is neither absent of choice nor absent of contract. It is the tradition. It is an arrangement made between families and is mandatory for the boy and girl to make an end of the childhood.Traditional marriage rituals were designed in times when social ngstructure was quite different. It was a patriarchal society where women were seen as dependent. A man can marry as many women as he want but this privilege was denied to the women, but man was bound by the rules of his family and his casteThe wedding rituals continue to be highly symbolic- where man is considered the farmer and the women is considered as the field. The child born from this union is called crop Description about horses has been mentioned in Ashwamedha yajgana. By King
Dashrath in Ramayana, Bhagwad Gita with Lord krishana riding a rath, kathoupnashid describing the meaning of chariot and in any marriage with the bridegroom the meaning of a chariot and in any marriage with the bridegroom riding a female horse.Kathoupnashid $(1.3,4-7)$ :- body as a chariot self as its master, five senses,ten senses,seventh is sun god sapthwahan sun represents control over the mind all seven days of the week Horses in vedic language symbolises the sense in the body. A female horse is much more chanchal than the male one and symbolises the childish behaviour of the person symbolises the childish behaviour of the person. Riding over the female horses means controlling the senses and leavving behind the childish behaviour as one is now entering into new phase of the life full of responsiblities. The ceremony involves riding the female horse and tightening of the rein. Traditionally 
weddings are held after chaturmass . The ritual is known as "tulsi vivah". Vishnu represented by sugarcane gets married to luxmi represented by the tulsi plant The event takes place in noon following the dust with Procession symbol, man is capable of carrying the sword and capable to protect the bride. The grooms in north india come over a mare and are covered with garland .The dalits are those who were refer to as chandalas, Ati shudras, Anaryas, Panchamas in the Hindu scriptures, they were Broken men and Protestant Hindu to Dr. Ambedkar and Harijan to Mahatma Gandhi. To Britishers they were Depressed classes and they were clubbed as the Schedule Castes under 1935 Act This was also adopted as administrative category in Indian Constitution. Dr. B.R. Ambedkar and Mahatma Jyotiba Phule were able to inculcate in their mind the values of self respect and diginity and urged them to fight for their rights Scheduled castes in haryana The total population of Scheduled Caste as per 2011 census is 201.4 millions constituting $16.6 \%$ of total population of India. There are 1241 indvidual ethinic groups are notified as scheduled castes in different states and union terrotery But Haryana accounts for 20.2 percent of total population. There are 37 Scheduled Castes enlisted in the Scheduled Castes list of Haryana.

The Census of 2001 has enumerated the population of 3 major SC groups namely Chamars, Balmikis, Dhanaks as they constitute $81.73 \%$ of SC population in Haryana. These 3 Scheduled Castes groups are 51.50, 19.20 and $11.03 \%$, respectively.

\section{Chamar}

The name Chamar is derived from the Sanskrit word Charmakara or worker of hides (Rose 1919). They have several subgroups namely Chanaur, Julaha, Chamar, Regar, Ravidasi and Jatavas. The traditional origin of the Chamar is that in time immemorial, four sadhus had a cow whose male calf died, upon its death the younger of these sadhus was asked to remove this calf's carcass, where upon he was deprived of his caste. The deprived sadhu out of poverty started doing leatherwork to work out its livelihood. It is perhaps from his association with leatherwork, other started calling him and his descendent Chamars. According to Rose (1919), Chan and Bane were two brothers. The former removed a calf's carcass with his own hand so Bane threw him out of the caste. They are found all over the state. Jamie is manly found in Faridabad and Gurgaon district and Chanaur in Mahendergarh, Hisar and Jind district. Julia Chama is thinly distributed through out the state. They are followers of Raids. Ambedkar and Kabir. They have small sub division called gots eg. Kem, Papal, Jhankar, Neemka, Nagaha.
They consider themselves inferior to Gujar, Jat, Rajputs, Brahmin. The Chamar own vegetable shop shoe shops, under take shoe repairing or engaged in agriculture and other labour work. Their economic conditon has improved since independence. They have a biradari panchayat which looks after the general welfare of the community and settle disputes. The Chamars are mostly Hindus but some of them embraced Buddhism, Islam and Christianity. On Ravidas Jayanti and Ambedkar jayanti they take out procession. Now due to reservation and modern education and other welfare programmes they are teachers, administrator, Bank, Defence, Police officers, Doctors, Engineers; Political leadership among them has emerged at village, state and national level, and now they have their own party BSP at national level. They prefer modern education for their children. This community among all Scheduled Castes has progressed considerably after independence in respect of social status.

\section{Balmiki}

The second numerically dominant Scheduled caste in Haryana is Balmiki. They are also known as Churha, Bhangi and Lalbegi. They claim to be descendent of Saint Balmiki, who wrote Ramayana. Their other guru is Lalbeg and it is after this guru's name, they are called Lalbegi. The Balmikis are distributed all over Haryana. They earn their livelihood by scavenging, working in the field and at the construction site; they are also engaged in animal husbandry, poultry, piggery; a few of them have land. The community's traditional primary occupation is scavenging including removal of nightsoils from houses and offices. Their secondary occupation include manual work band, petty trade, hawking, vending, fruits or vegetables, selling meats and eggs. They have their own caste panchayat who decides matter of social conflict. Due to reservation and modern education, some members of this community are Businessmen, Teachers, Doctors, Engineers, Administrators, Defence, Police and Railway officers. Political leadership among them is at budding stage.

\section{Dhanak}

Dhanak are also known as Kabirpanthi Julaha. They claim to be the descendents of Dhanushamuni Ibbestson (1916) derives this name from the Sanskrit Dhanuska, a bowman. According to T.H. Elliet, they are followers, archers and watchman, besides performing other menial services. They are found in all districts of Haryana. There are small sub. Division called Gots in the community Nugaria, Khangwal (Khanna), Nonania (nayyar), Khatak, Kirar, Mudadiya, Ladwal, Morwal, Bamania, Mohal, Bagadi, Suraha, Salia, Mohar etc. are main gots of Dhanak. They 


\section{EPRA International Journal of Multidisciplinary Research (IJMR) - Peer Reviewed Journal}

Volume: 6 | Issue: 3 | March 2020 || Journal DOI: 10.36713/epra2013 || SJIF Impact Factor: 5.614||ISI Value: 1.188

perceive themselves as equal to other SC communities. They admit the verna system and find their place with Shudras.

They are taking full advantages of the government's reservation policy, and supposed to occupy a parallel position with Bhangis on the social ladder. They earn their livelihood by working as agricultural, construction and roadside laboures. Some of them are also engaged in Poultry, Piggery, Textile dying and Printing. They have their own panchayat and caste council. They workship Kheri, Sampla, Gurgaon wali Mata, Phoolam de Mata (Rohtak). Pathriwali Mata at Gohana and Beri wali mata. Due to job reservation and modern education some of them are Teacher, Police Bank, Administrative, Railway Officers and Military men. Literacy among them is very low, but they are in favour of children's education. Political leadership among them has emerged at regional level and trying to get their share.

Among dalits a dalit middle class emerged due to policy of reservation in jobs and educational institutions. Life styles of Lesser Indians have changed in consumption pattern. Small business,.cars and kothis are visible in dalit areas. They felt confident in articulating their experiences of discrimination at work place and continuous caste based discrimination against them in all walks of life.The Constituiton of india provide equal rights in all walks of life to all its citizen. But even after 72 years of independence and 70 years of commencement of indian constitution, dalits are not able to ride a mare during the marriage procession. If they challenge this hegemonic tradition of indian society, it always led to violence against them and murders if they took it even in the presence of the police.

- Some recent incidents of violation rights of dalit to ride mare and carry out marriage procession

Rewari (20/6/2002)- kund vijaynagar- no dalit can ride mare in the marriage. No dalit could sit on mare in presence of thakur. Sarpanch said it will not be tolerated. Among bawaria community has two horses but can not ride. Kartar singh , Hoshiyaar singh took out marriage procession on mare under police protection and were boycotted in the village.

- Jatu Luhari ( November 11,2002)- dalit groom and family members severely injured during marriage procession on the mare and attacked by the upper caste.

- Rohtak- upper caste youth stopped dalit's gurchari in banyani village (26 June 2012)
- Devsar- upper caste men prevented dalit groom from riding the elephant. Daring to break the age old tradition, he was killed later on after tied him with a tree and hiting by the car ( 4 december 2011,16 April 2013).

- Bhusthala(23 May 2016)- dalit man was stopped from riding a horse cart during his wedding ceremony by the upper caste and pelted stones even in presence of police

- Kanalsi- upper caste people forces the dalit groom to come down of the horse (16 October 2017)

- Sanjarwas- upper caste people people stopped the dalit groom from carrying out marriage ritual of ghurchari completed in police presence in the dalit locality (2017 Kaithalman shot in haryana after the quarrel over high volume of DJ in wedding procession (10 December 2012)

- Pabnawa (karnal)- Dalit were attacked after inter caste marriage in Haryana,dalit locality attacked,water supplycut after inter-caste marriage in haryana (April 15,2013),

- Sohola (Ambala)-the upper caste opposed a dalit groom performing ghurchari, stopped paying tribute to a gram devta the dalits were injured. (2010) Violence had broken out in the village Sagha Karnal after uppercaste prevented the dalit groom from carrying the marriage ritual of ghurchari (2017 Ratera uppercaste men beaten dalitgroom and forcibily stopped him from performing gurchari( march 1,2013)

- Protest ideology

- They believe in destruction of traditional, hegemonic unethical restricted world view that consider them as lesser Indians not equal Indian and equal citizen by their Bahujan perspective.

- There are many young performers on the scene today and its the younger generation that make up most of the evidence at these events

- Marriage is solmanised according budhhism and no fera system(a hindu marriage ritual) The stage is decorated with $\mathrm{Dr}$ Ambedkar,Lord Buddha in center

Bhim Jagran, Ravidas ,mahrishi valimiki manwar kashram - sant kabir songs and new songs These songs has played in transforming society in recent times. 
- Hindu marriage Songs performed by women has been replaced by Bahujan philosophical songs.

- Dalit orchestras- used songs of self respect, assertion, awakening, , contribution of bahujan heroes in challenging cultural hegemony of casteHindus

- Challenge hegemonic cultural system

The folk songs and ballads speaks of equality and fraternity of this community. Sociological relevance of the study

1 In interrogating the caste atrocities, we need to take a serious cognizance of the existing social relations between caste Hindus and Dalits.

2 In all cases, whenever there are atrocities committed on the scheduled castes by the upper caste, there exists a significant amount of conflict between two groups.

3 Individual act of challenging hegemonic cultural tradition are treated as community crime . in conclusion I can say that there is equilibrium in the social relationship as long as the scheduled castes submit to their humiliating demands of caste Hindu or the later are so enlightened as to treat the scheduled castes as equal Indian ,as ,equal hindu fellow, equal citizens not as Lesser Indian and lesser citizens which is however only a hypothetical? There is a need of progressive mindset of especially law implementing authorities to curb such atrocities against the scheduled castes for a just society

\section{REFERENCES}

Newspapers

1. the hindu

2. the tribune

3. Hindustan times

4. the times of india

5. dainik bhaskar

6. Indian express

7. Punjab kesari

8. amar ujala

9. economic times

Magazines

1. tehlka

2. hum dalit

3. india today

1. Reports of national commission for schedule caste and schedule tribes

2. Ambedkar volume writing and speeches

3. Vidhan sabha debates

4. Reports of non-governmental association like PUCL, PUHR, PUDR, DAG

5. Report of national commission of human rights 